\title{
BIOPSYCHOSOCIAL AND INSTITUTIONAL FACTORS ASSOCIATED WITH EXCLUSIVE BREASTFEEDING AMONG WORKING MOTHERS IN KLATEN, CENTRAL JAVA
}

\author{
Desi Ekawati1), Harsono Salimo²), Bhisma Murti1 ${ }^{1)}$ \\ 1)Masters Program in Public Heath, Sebelas Maret University \\ 2)Department of Pediatrics, Dr. Moewardi Hospital, Surakarta
}

\begin{abstract}
Background: Breast milk has an important role in health maintenance and survival of infants. It is acknowledged as the best food for infant. The World Health Organization has recommended exclusive breastfeeding (EBF) for infants until 6 months of age. However, many working mothers did not provide EBF to their infants. This study aimed to examine biopsychosocial and institutional factors associated with exclusive breastfeeding among working mothers, using health belief model and PRECEDE-PROCEED model.

Subjects and Method: This study was observational analytic with cross sectional design. It was conducted in Klaten District, Central Java, from March to April, 2017. A sample of 120 working mothers was selected for this study by simple random sampling. The dependent variable was exclusive breastfeeding. The independent variables were maternal education, perceived benefit, perceived barrier, self efficacy, family support, health personnel support, and availability of lactation room at workplace. The data were collected by a pre-tested questionnaire. Logistic regression was employed for data analysis.

Results: Maternal education $(\mathrm{OR}=4.2 ; 95 \% \mathrm{CI}=1.09$ to $11.51 ; \mathrm{p}=0.001)$, availability of lactation room at workplace $(\mathrm{OR}=4.11 ; 95 \% \mathrm{CI}=1.21$ to 14.29 ; $\mathrm{p}=0.001)$, family support $(\mathrm{OR}=6.25 ; 95 \% \mathrm{CI}=1.45$ to $15.96 ; \mathrm{p}<0.001)$, health personnel support $(\mathrm{OR}=3.76 ; 95 \% \mathrm{CI}=1.43$ to $16.06 ; \mathrm{p}=0.002)$, perceived benefit $(\mathrm{OR}=2.30 ; 95 \% \mathrm{CI}=1.09$ to $12.87 ; \mathrm{p}=0.044)$, self-efficacy $(\mathrm{OR}=3.57$; $95 \% \mathrm{CI}=1.21$ to $14.29 ; \mathrm{p}=0.002$ ) had positive effect on EBF. Perceived barrier $(\mathrm{OR}=0.18 ; 95 \% \mathrm{CI}=0.64$ to $0.76 ; \mathrm{p}<0.001)$ had negative effect on the provision of EBF.

Conclusion: Maternal education, availability of lactation room at workplace, family support, health personnel support, perceived benefit, self-efficacy have positive effect on EBF. Perceived barrier has negative effect on the provision of EBF among working mothers.
\end{abstract}

Keywords: biopsychosocial factors, exclusive breastfeeding, PRECEDEPROCEED model, health belief model

Correspondence: Desi Ekawati. Masters Program in Public Heath, Sebelas Maret University, Jl. Ir. Sutami 36 A, Surakarta, Central Java.

Email: eccadesy@yahoo.com. Mobile: +6285725123320. 